\title{
Development of Mobile Learning Module Based on Student's Learning Style for a Mechanical Engineering Education Course
}

\author{
Wisnu Dimas Sasongko ${ }^{1}$, Indah Widiastuti ${ }^{1}$, Budi Harjanto ${ }^{1}$ \\ ${ }^{1}$ Mechanical Engineering Education, Faculty of Teacher Training and Education, Sebelas Maret \\ University, Surakarta \\ Email: wisnudidim@gmail.com
}

\begin{abstract}
Recent advancements in the capabilities of mobile devices have led to an increased interest in leveraging them for learning, especially in the field of engineering education. Mobile learning has become great tool for delivering educational resources in which learners can not only access the module anytime and anywhere but also can actively interact with the learning material. This research aims to design and develop learning material of an automotive engineering course based on mobile device for mechanical engineering education students. The development epublication module of motorcycle mechanic course employed the ADDIE instructional design model encompassing five steps: analysis, design, development, implementation, and evaluation. The student's learning style was identified to characterize the target audience of the mobile module. It was found that the majority of the students as the user have auditory and kinesthetic, then the module will be designed with the design in accordance with the auditory and kinesthetic learning style, therefore the module will be mainly designed on audio-based format. The learning module is developed using e-publication software consisting of structured PDF documents combined with audio and video files. Some experts in instructional system design and automotive engineering were asked to evaluate the implementation feasibility of the module. The average evaluation score was $85.4 \%$, indicating high acceptance of implementing the learning module. The technical feasibility analysis indicated that the smartphone used for this module requires at least 1024 MB of RAM (Random Access Memory). It implies that e-publication module delivery has the potential to gain wider acceptance in engineering education complementing the in-class and practical learning.
\end{abstract}

\section{Keywords: development; instructional media; ADDIE model; e-publication; mobile learning}

\section{INTRODUCTION}

Advances in technology have brought changes in the development of instructional design. Utilization of information technology is increasingly used in the learning process. The development of e-learning is increasingly intensive in supporting the learning process, not only for distance learning, but also for classroom learning. With the development of smart phone technology, m-learning-based learning becomes one of the alternatives of instructional design which is quite flexible and efficient. Sun and Cheng [1] showed that the digital learning is considered to be more attractive. This finding is supported by Greener et al [2] which 
concludes that students appear to be more enthusiastic in learning activities using digital technology than non-digital media.

In engineering education, students are expected not only to be able to understand the concept of a material but also to provide solutions of a problem. Self learning is required to support the classroom learning. However, use of paper-based modules is less effective for engineering education since it requires visualisation of the content. Digital content is considered appropriate for engineering education as according to Nielsen and Kreiner [3] that students who use digital books for learning have a higher affective and psychomotor learning compared to the ones using textbooks. As a new platform in educational environment, mobile learning management system is considered to be highly adaptive to student learning styles [4].

This research is aimed to develop instructional media in Motorcycle Engineering course as one of the subjects of mechanical engineering education by modifying the module to be more interesting and effective. The development of learning module is quite appropriate for engineering education as the module systematically arranged to contain a set of lesson plan [5]. The module has been developed based on epublication which means as a digital book format that has become the official standard of International Digital Publication Forum (IDPF). It consists not only text but also audio visual files. It has been indicated that the use audio-visual material in learning process may improve learning outcomes and increase student motivation [6, 7]. Technically, the module will be implemented on smartphone devices as they can support collaborative learning and enhance the student motivation [8]. Smartphone device was choosed since this device is quite popular among the student. The use of smartphone bring easiness access of the learning content anytime and anywhere. The instructional material used in the learning process should consider the learning style needs of the students [9]. Therefore, it is important that the development of a learning module should be based on the learning styles of students in the classroom.

\section{METHOD}

This research develops a learning module using a procedure following to the ADDIE model. This model is composed of five main stages including analysis, design, development, implementation, and evaluation [10].

\section{Analysis}

This stage aims to analyze the users need to ensure the alignment of the module with the requirement of the users. In this study the analysis stage consists of analysing the students' learning style, content of the module, and characteristics of the students. The instrument used is well established comprising of 16 questions with 4 answer points that represents a person's learning style in every statement. The instrument used for evaluating the learning style is a VARK-based questionnaire [11] consisting of 16 statements which describes the type of respondent learning style. The same questionnaire has been tested also by Ismantohadi et al [12] which concludes that the VARK learning style approach can facilitate learners in receiving learning information. The questionnaire was distributed to several students of the Mechanical Engineering Education Department Sebelas Maret University taking the course of Motorcycle Engineering.

Learning style analysis is the main analysis used as the basis for the development of e-publication module; this analysis aims to develop media in 
accordance with the learning style of the user. The evaluation of the learning style of 30 students of Motorcycle Engineering courses is shown in Figure 1. It is indicated that the majority of potential users have the type of auditory learning style with a percentage of $31.25 \%$ and kinesthetic with a percentage of $29.8 \%$.

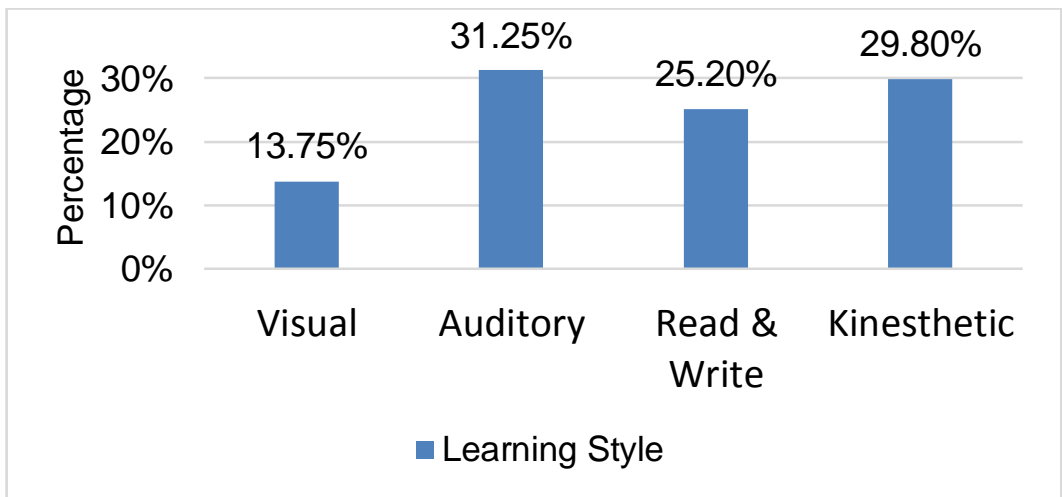

Figure 1. The evaluation of the learning style

\section{Design}

In this stage, the module is designed according to the student learning style. This stage also dedicated to design the module by compiling the content corresponding to the sylabus. The design stage also covers all the activities related to developing the module using the e-pub software. A set of storyboard was also developed for audio and video content in the module.

\section{Development}

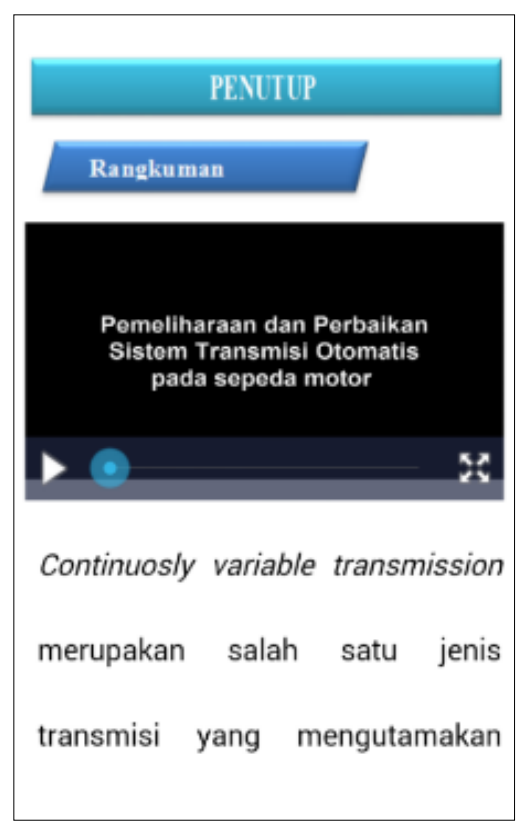

Figure 2. Audio visual on e-publication module

According to the design, the module was developed using a special software for e-publication in which the program is generated media in the form of e-publication with file extension .epub. The module is developed based on the results of analysis of learning style majority of candidates Users in the form of auditory and kinesthetic 
learning styles. Both learning styles are used as the basis for the development of epublication module. Figure 2 shows the windows for the e-publication module developed in smartphone devices.

\section{Evaluation}

Evaluation of the module was perfomed by distributing an assessment test to 4 (four) instructures of the course. The assessment instruments obtained from the standard developed by the Chamber of Nation Education Standard. Quantitative data from the questionnaire is then converted into qualitative data by using Likert scale. . In addition to quantitative data, qualitative data in the form of criticism and validator suggestions are also used as the basis of media revision before the responses are made to the lecturers of course lecturers. Evaluation stage is performed to measure the feasibility of the module to implemented for supporting the learning process.

\section{RESULT AND DISCUSSION}

The evaluation of the learning style of 30 students of Motorcycle Engineering courses is shown in Figure 1. Figure 1 shows that $31.25 \%$ users have an auditory learning style and $29.8 \%$ among them are kinesthetic learner. According to this fact, the mobile based modul will be developed accentuates auditory and kinesthetic aspects. Learning styles are very important in giving student alternative to choose their own distinctive learning and in creating attractive learning environment for students [13]. The stage after the analysis is the development stage, in the stage of direct execution of the media with the material that has been prepared in the design phase and the results of the analysis. The next stage is assessment of the module in which four evaluators assess its feasibility level. Assessment of the module is performed by four evaluators, which is shown in Table 1

TABLE I. THE ASSESSMENT EXPERT

\begin{tabular}{|lll|}
\hline Evaluator & Score & Percentage \\
\hline 1 & 66 & 82.5 \\
2 & 65 & 81.25 \\
3 & 75 & 81.5 \\
4 & 89 & 96.7 \\
\hline \multicolumn{2}{r}{ Average } & 85.4 \\
\hline
\end{tabular}

The average score for the assessment of the mobile-based module is $85.4 \%$, which converted into qualitative scale as excellent. Thus, the e-publication module developed is considered feasible to be implemented in the learning process. The evaluators were also provide assessment on the appearance, content and expediency of the mobile-based module for engineering education. The module is considered to have positive impact for independent learning. Among other things modules can be improved in terms of quantity, and for the list of libraries should be a source that can be accounted for, then in terms of media e-publication module as much as possible accessible in the computer and the last device to be repaired is not appropriate spelling.

The module is developed to be operated in a mobile device, which requires a specified requirement to optimally utilize the module [14]. For that purpose, a series of test was performed to determine the ability of a software with a certain memory 
capacity in running all functions of mobile-based application module on the smartphone. It was found that the module requires a mobile device with a minimum capacity of $1024 \mathrm{MB}$ to run the module optimally.

\section{CONCLUSION}

This paper describes the process in developing an e-publication for Motorcycle Engineering course. It follows the ADDIE development model. The assessments from some evaluators indicate that mobile-based module is feasible to be implemented in learning process. The module requires mobile device with certain specifications. The technical testing of the device found that the mobile device should have at least $1024 \mathrm{MB}$ of RAM (Random Access Memory) capacity. This implies that e-publication module has the potential to gain wider acceptance in engineering education complementing classroom learning.

\section{REFERENCES}

[1] Sun, P. C., \& Cheng, H. K. 2007. "The design of instructional multimedia in e-Learning: A Media Richness Theory-based approach". Computers and Education, 49(3), 662-676. https://doi.org/10.1016/j.compedu.2005.11.016

[2] Greener, S., \& Wakefield, C. 2015."Developing Confidence in the Use of Digital Tools in Teaching”. Electronic Journal of E-Learning, 13(4), 260-267. https://doi.org/10.5430/ijhe.v3n1p94

[3] Mulholland, E., \& Bates, J. 2014. "Use and Perceptions of E-books by Academic Staff in Further Education". Journal of Academic Librarianship, 40(5), 492-499. https://doi.org/10.1016/j.acalib.2014.05.018

[4] Park, Hyungsung. 2005. "Design and development of a mobile learning management system adaptive to learning style of students". 67 - 69. 10.1109/WMTE.2005.14.

[5] Dikmenjur. 2004. "Pedoman Penulisan Modul”. Jakarta: Dikmenjur, Depdiknas.

[6] Aprianti, R., \& Budi, E. 2015. "Pengembangan Modul Berbasis Contextual Teaching and Learning (CTL) Dilengkapi Dengan Media Audio- Visual Untuk Meningkatkan Hasil Belajar Fisika Peserta Didik SMA”. Prosiding Seminar Nasional Fisika (E-Journal) SNF2015,IV,137-142.

[7] Simo, P., dkk. 2010. "Video stream and teaching channels: Quantitative analysis of the use of lowcost educational videos on the web". In Procedia - Social and Behavioral Sciences

[8] Chuang, Y.-T. 2015. "SSCLS: A Smartphone-Supported Collaborative Learning System". Telematics and Informatics, 32(3), 463-474. https://doi.org/10.1016/j.tele.2014.10.004

[9] Al Khasawneh, E. 2013. "Using VARK To Assess Changes In Learning Preferences Of Nursing Students At A Public University In Jordan: Implications for teaching'. Nurse Education Today, 33(12), 1546-1549. https://doi.org/10.1016/j.nedt.2012.12.017

[10] Molenda. 2003. "In Search of the Elusive ADDIE Model". Indiana University

[11] Vark a Guide to Learning Styles. (2016). http://varklearn.com/

[12] Ismantohadi, E., Edi Nugroho, L., \& Suning Kusumawardani, S. 2015. "Prototipe Sistem ELearning dengan Pendekatan Gaya Belajar VARK (Kasus: Politeknik Indramayu)". Jurnal Nasional Teknik Elektro Dan Teknologi Informasi (JNTETI), 4(3). https://doi.org/10.22146/jnteti.v4i3.156

[13] Othman, N., \& Amiruddin, M. H. 2010. "Different perspectives of learning styles from VARK model". In Procedia - Social and Behavioral Sciences (Vol. 7, pp. 652-660). https://doi.org/10.1016/j.sbspro.2010.10.088

[14] Herrera, S., Fennema, M., \& Morales, M. 2015. "Mobile technologies in engineering education". Proceedings of Interactive Collaborative Learning (ICL) 2015. http://ieeexplore.ieee.org/abstract/document/7318197/ 